\title{
THE ROLE OF LOCAL WISDOM AS RELIGIOUS CONFLICT RESOLUTION IN JAMBI INDONESIA
}

\author{
ABDUL HALIM ${ }^{1}$, PAHRUDIN HM*2 \\ ${ }^{1}$ UIN Sulthan Thaha Saifuddin Jambi \\ ${ }^{2}$ Universitas Jambi
}

\section{Abstract}

This research aims at analyzing the potential for social conflict, especially religious conflict related to the establishment of houses of worship in Jambi. This study was conducted by employing a qualitative research approach with a type of case study research. This research was conducted in three districts in Jambi (Telanaipura, Alam Barajo, and Kotabaru). The results show that as a plural city, Jambi is not spared from the conflict of the establishment of places of worship that occurred in three regions. However, the previous conflicts that occurred were not prolonged because the people of Jambi still adhered to the wisdom of the local culture in the form of Seloko Adat which internalized through family, education, and the environment. As a significant potential of a conflict resolution, however, the Jambi society in general are lack of understanding of Seloko Adat.

Penelitian ini bertujuan menganalisis potensi konflik sosial, khususnya konflik agama terkait dengan pendirian rumah ibadah di Jambi. Penelitian ini dilakukan dengan menggunakan pendekatan penelitian kualitatif dengan jenis penelitian studi kasus. Penelitian ini dilakukan di tiga kabupaten di Jambi (Telanaipura, Alam Barajo, dan Kotabaru). Hasil penelitian menunjukkan bahwa sebagai kota yang plural, Jambi tidak luput dari konflik pendirian tempat ibadah. Namun, konflik yang sejauh ini terjadi tidak berkepanjan-

\footnotetext{
* Corresponding author: Jl. Raya Jambi - Muara Bulian Km. 15, Mendalo Indah, Jambi Luar Kota, Jambi 36361. Email: pahrudinhm9@gmail.com.
}

ISSN 0852-7172 (p) 2461-064X (e)

(C) 2019 Walisongo: Jurnal Penelitian Sosial Keagamaan

http://journal.walisongo.ac.id/index.php/walisongo 
gan karena masyarakat Jambi masih mengamalkan kearifan budaya lokal dalam bentuk Seloko Adat yang diinternalisasi melalui keluarga, pendidikan, dan lingkungan. Namun, sebagai potensi resolusi konflik yang signifikan, masyarakat Jambi pada umumnya kurang memahami Seloko Adat.

Keywords: house of worship; local wisdom; religious conflict; safety-valve.

\section{Introduction}

The study of religious conflict in Indonesia, especially related to the establishment of worship houses, is an important theme and object of research. As a plural country in terms of religion, ethnicity and culture, Indonesia has the potential for social conflict. As is known that Indonesia has six officially recognized religions by the state, namely: Islam, Christianity, Catholicism, Hinduism, Buddhism and Confucianism and hundreds of ethnic groups and thousands of cultures. Theoretically, the plurality inherent in a nation has the potential to cause divisions or conflicts among the people in it (Boedhi Oetojo et al. 2010). This condition does not only undergo in countries that are categorized as developing, such as Indonesia, but also in developed countries though, such as Britain with Scot tribal conflicts and Welsh and French tribes with the conflict of the Breton tribes. In Indonesia, conflict always adorns the nation's journey, starting from smallscale conflicts involving small groups in society (brawls between residents) to large-scale conflicts, such as in Ambon (Maluku), Palu (Central Sulawesi), Sampit (West Kalimantan), Banyuwangi (East Java) and so on.

According to Suaedy (and Rumadi 2007, 247), the history of religious conflict in Indonesia notes that places of worship have always been a source of conflict which often leads to destruction and burning. The existence of religion in the community 
is represented through a double face (Kimball 2008). On the one hand, religion appears with a positive face through a set of morals and ethical values for its adherents. On the other hand, religion emerges with a negative face for it turns to be the source of a series of conflicts that occur due to the misunderstanding of its followers and exclusive attitudes. The existence of this double-faced religion raises many debates among experts and thinkers. Religion is recognized as a basic need for humans because it has rarely been found in history that there were people who were not religious (Agus 2006, 33).

Cases of religious conflict in Indonesia show the role of religion in social interactions carried out by Indonesian people. As the creature of God that their life experiences do not always go well and are frequently overshadowed by failures, humans need religion as a place to escape from such things. It is in this context that religion performs its function to help humans overcome the various obstacles faced in the course of their lives (Robertson 1993, x). On this basis, the study found its urgency in the form of conversation around the presence of religions in the midst of our daily lives. Its existence, apart from being an integrative factor, is also often a factor in the emergence of disintegration, tension, and conflict between fellow believers of religion and / or religion, even more radically, religion is also sometimes a factor in a nation's war. This is what later underlies religious observers to conclude that the existence of religion in the midst of society is represented by either positive faces on the one hand or negative faces on the other (Kimball 2008). Religion-labelled Issues which often have an impact on intolerant attitudes among fellow religious followers, are indeed too frequent up to now. The potential for the development of religious conflict is more prone to occur in a society or country in which the population adheres to multi-religion like Indonesia. This case can occur since each 
party certainly has its interests which are different, even conflicting, with other groups. The differences of desires and interests will, in turn, lead to conflict, both on a small, medium and large scale.

Theoretically, it is indeed said that plurality inherent in a nation or region has the potential to cause divisions or conflicts among the people in it (Nasikun 2004). Based on a study conducted by Suaedy and Rumadi $(2007,247)$, the history of religious conflict in Indonesia notes that places of worship have always been a source of conflict which often leads to destruction and burning. However, what is assumed above does not occur in Jambi City as a plural area of various aspects, especially from the plurality of religions held by its citizens. Geographical and demographic elements, Jambi City, has an area of $205.38 \mathrm{~km}$ with eight sub-districts and a total population of 576,067 people, with details of 289,713 men and 286,354 women (Badan Pusat Statistik 2016). Sociologically, the composition of the population of Jambi City based on ethnicity is quite diverse, ranging from Javanese, Sundanese, Palembang, Batak, Minangkabau, Bugis, Banjar, Arabic, Indian and Chinese. Although, among them, Malays become the majority group (Lindayanti, Noor, and Hariadi 2013, 209) and embrace various religions, such as Islam (as the majority), Christians, Catholics, Hindus, Buddhists and Khong $\mathrm{Hu} \mathrm{Chu}$ (Badan Pusat Statistik 2016). Related to this, based on a study conducted by Abdullah Idi (2012), Suprapto (2013), Bakri (2015), Mufid (2010), and Ridwan Rosdiawan et al. (2007) it is shown that local wisdom that grows and takes root in the traditions of the people in various regions in the country can be used as an antidote to conflict.

In relation to what has been described above, the issue of local cultural wisdom as a damper of religious anarchist conflict in the case of the establishment of houses of worship in Jambi 
City, Indonesia deserves further study. This is because as a plural society, Jambi City has the potential to cause conflict, especially if it looks at the diversity of religions held by its inhabitants. The wisdom of local culture originating from customs and traditions of local people is believed to be able to counteract the emergence of conflicts, as happened in various parts of Indonesia.

\section{Literature Review}

\section{Local Culture Wisdom}

Local wisdom was first introduced by Quaritch Wales (1948-1949). The phrase was interpreted as the ability of the local culture to deal with the influence of foreign culture at the time the two cultures were related (Mariane 2014, 111). In general, local wisdom (indigenous knowledge or local knowledge) can be understood as ideas that are born and developed in the local domain that contain wise and ethical values followed by all members of the community (Trubus Rahardiansyah and Prayitno 2011, 59). It is also related to indigenous knowledge, wealth of knowledge and culture in certain societies that are always developed from time to time and continue to experience development and change. There are at least four indicators that serve as benchmarks for tracking local wisdom, i.e., the treasure of knowledge based on local knowledge, experiences changes from time to time, lives and is known in specific community environments and changes and dynamic. The forms of local wisdom include the belief in maintaining the environment, health and daily life of the community members.

Furthermore, it recognizes four main characteristics, i.e., generalist, where there is a tendency for supporters of local culture to know a little about many things. This typology contrasts with intellectuals who have specialized in their skills, with the great deal about a few things. Local wisdom also relates to the local social system to form a holistic society, namely completing 
a case based on the knowledge of those who are not cases of cases. If sorted out more carefully, there will be a correlation between local wisdom and local culture and religion. Religion is an integral part of a culture. In rural communities, local wisdom relating to various elements of culture has the potential to minimize risk rather than maximize profits.

Based on Sartini's review $(2009,12)$ it is concluded that local wisdom is a personality, cultural identity of the community which consists of values, norms, ethics, beliefs, customs and special rules that are accepted by the community and tested so that they can survive continuously. Furthermore, Sartini $(2009,12)$ states several aspects imply characteristics of local wisdom, i.e., good value, based on religious understanding and experiences related to nature, in the form of knowledge, ideas, norms, methods, behaviours and other types of activities. They can be physical or non-physical originating from specific local communities and growing within them for they are used continuously can be rationalized, and contextual to the current living conditions.

Local wisdom is also interpreted as a personality identity of a nation that enables to absorb and cultivate foreign cultures according to their characteristics and abilities (Ayatrohaedi 1986, 18). Local wisdom is also understood as cultural knowledge possessed by certain communities which include several cultural knowledges related to models of sustainable use and management of natural resources (Zakaria 1994, 56). The concept of local wisdom refers to the method of utilizing natural resources initiating from the culture of the local community as mentioned earlier that in human history there are people who are aware and concerned about the preservation of nature and groups of people like this that local wisdom originates. People who have natural care then create simple rules that were initially obtained through a trial $\&$ error process by continuing activities that are 
believed to be able to preserve nature and abandon practices that lead to damage (Mitchell, Rahmi, and Setiawan 2003, 299).

\section{The Conflict Concept}

Etymologically, conflict originates from the Latin word "Configere" which is interpreted as hitting each other, then adopted by English into "Conflict" (Wirawan 2012, 4). Terminologically, conflict is understood by many people in various senses. Pickering (in Fisher et al. 2000, 4), for example, defines conflict as the existence of several competing or out of tune choices. Meanwhile, conflict is understood by Fisher $(2000,4)$ as a relationship between two or more parties who have, or feel they have goals that are not in line. While Roxane S. Lulops and Dudley D. Chan $(2000,3)$ explain conflict as two or more reactions that conflict with an event, or differences between two individuals, the existence of mutual hostility between groups, or the existence of a problem that must be resolved. According to Wirawan (2012, $5)$, conflict is a process of conflict that is expressed between two or more interdependent parties regarding conflict objects, using behavioral patterns and conflict interactions that produce conflict outcomes.

Historically, conflict theory emerged as a reaction to functional, structural theory carried out by Talcott Parsons in mid1950-1960 which was considered to be the denial of the phenomenon of conflict that existed in society (Sindung 2012, 39). Conflict, also known as disintegration and imbalance, for Parsons and several other sociologists, such as Durkheim and Merton, is a social problem that can disrupt harmony, balance, integration and stability which in turn will lead to dysfunction in aspects of broader life (Johnson 1998, 99-107). In contrast to structural, functional adherents, those who consider conflict as something positive believe that conflict becomes the central element of social life (Jalaludin 2015, 36). For those who are then 
referred to as conflict theorists, conflict is something normal and inevitable in social life. The leaders of the conflict theory are such as Karl Marx, Max Weber, Ralf Dahrendorf, Lewis Coser, Gyorgy Lucacs, Randal Collins, C.W. Mills and Gerhard Lenski (Poloma 2004).

This study is analyzed through the conflict theory by Lewis A. Coser. Several reasons are worth mentioning related to the choice of Coser conflict theory as an analytical tool in this study. First, the conflict theory produced by Coser offers something different from the others, namely describing social conflict as a result of conflicting group interests and its focus on the consequences of conflict (Sindung 2012, 51). Second, Coser proposes a Safety valve as a mechanism or a way to maintain groups from the possibility of social conflicts (Poloma 2004, 108).

According to Coser (in Poloma 2004, 107), the conflict has positive implications for a social life because it is the settler and guardian of the boundary between two or more groups. It also can strengthen the identity of the group and protect it so that it does not dissolve in the social world around it. Coser believes that violence and conflict can encourage social change in society. Coser shows how conflict has a positive function, especially in increasing social integration when the issue of conflict is open, and the conflict regulation mechanisms are developed to deal with the impact. Inter-group conflict escalates solidarity among the conflicting groups. This is often followed by the formation of an alliance between them.

Based on the need for resolution or handling of conflicts, Coser suggests a mechanism that can prevent the occurrence of social conflict. Coser (in Poloma 2004, 108-9) calls this conflict prevention mechanism a safety valve, a unique mechanism that can be used to defend groups from possible social conflicts. This mechanism serves as a solution that eases hostility, because 
without this, the relations between the opposing parties will be even sharper. The 'Rescue Valve' allows the outburst of hostility to be channelled without destroying the entire structure. Conflict, in this case, cleanses the atmosphere in a chaotic group. This system functions as an 'easing out hostility', without which the relations between opposing parties will become increasingly sharp (Coser 1956, 41). The Safety valve implementation offered by the Coser can manifest in various forms. The safety valve can be a representative body that provides a means to express complaints and problems faced by its members. This mechanism can also be in the form of a lecturer welfare committee which is the mouthpiece of the lecturers voicing the issues they face. In essence, the Safety valve functions as a regulator of the possibility of conflict and indirectly impedes the development of conflicting groups that can lead to change through conflict (Coser 1956, 109). Because of its function as a barrier to conflict, the Safety valve does not have to be in the form of an institution, but it can also be in the form of culture, customs or local wisdom that is believed by the community. This local wisdom is used as a Safety valve that blocks or avoids community groups from the possibility of social conflict.

\section{Methods}

This study uses a qualitative research approach. It is an approach that allows researchers to be able to carry out detailed descriptions and interpretations to gain a holistic understanding (Denzin and Lincoln 2009). This type of research is a case study (case study), which is a type of research that can be interpreted as an approach to study, explain, or interpret a case (case) in its natural context without outside intervention (Creswell and Poth 2007). More specifically, this research is instrumental case study (instrumental study) which is used to examine a particular case so that a perspective can be presented on the issue or improve- 
ment of a theory (Denzin and Lincoln 2009, 301). The research was conducted in Jambi City, Indonesia, especially in the three regions; Telanaipura District, Alam Barajo District, and Kotabaru District. These three regions are claimed to be the most plural areas in Jambi City and the most standing places of worship besides Islam, namely the church and monastery.

\section{Data Collecting}

As required in qualitative research using the case study method, the data is collected from several sources; through documents and archive records, interviews, direct observation, (participant observation) and other physical devices related to religious conflict in Jambi City (Yin 2004, 103-18; Crabtree and Miller 1999, 14-17).

\section{Data Analysis}

As an effort to analyze the data that has been obtained and collected, qualitative data analysis techniques are used in three ways; data reduction, data presentation (displaying data), and concluding (Miles and Huberman 1992, 88-90).

\section{Results and Discussion}

\section{The vulnerability of conflict in Jambi City}

As an urban area that is developing far more rapidly than other regions in Jambi Province, Jambi City has long been known as an open area to various migrants from within and outside the country. This is most likely closely related to its position as the capital of the Jambi Sultanate (formerly) and Jambi Province (after the independence of the Republic of Indonesia). In addition, it is known for its existence as a trading area for various kinds of natural resources in the Jambi Province, such as rubber, pepper, cloves and wood. 
In the beginning, Jambi City was known as an export port for Minangkabau (West Sumatera) hinterland products, such as gold and pepper. Along with the transfer of power to the Dutch Colonial that introduced rubber and petroleum, Jambi City turned into a port of export for products, especially rubber. As a result, the economy of Jambi City experienced a significant increase compared to its previous times. This situation certainly does not only have an impact on the welfare of the people of Jambi City, but also has implications for the swift flow of incoming migrants. Therefore, the composition of the population of Jambi City based on ethnicity is quite diverse, ranging from Javanese, Sundanese (West Java), Palembang (South Sumatera), Batak (Nort Sumatera), Minangkabau (West Sumatera), Bugis (West Sulawesi), Banjar (South Kalimantan), Arab, Indian and Chinese. Yet, still, Malays are the majority ethnic (Lindayanti, Noor, and Hariadi 2013, 209).

Even though they are from various ethnic groups or known as plural (plural) societies, throughout history, there has never been a horizontal conflict in Jambi City (Lindayanti, Noor, and Hariadi 2013, 6). Theoretically, it is indeed said that plurality inherent in a nation or region has the potential to cause divisions or conflicts among the people (Nasikun 2004). Not only in terms of ethnicity, but the diversity of aspects of religion is also inherent in Jambi City. In general, it can be said that as a capital as well as a miniature of the province, the population of Jambi City adheres to various religions, such as Islam, Christianity, Catholicism, Hinduism, Buddhism and Confucianism. However, Muslims become the majority. Despite being composed of diverse ethnicities and religions, or known as a pluralistic society, throughout its history, there has never been a horizontal conflict in Jambi City.

Even so, there are some conflicts still occurring, mainly related to the building of religious worship houses that belong to 
minorities in Jambi City. Among the conflicts was the story that involved a group of Batak Christian religious leaders who came to the Penyengat Rendah area in the Telanaipura District of Jambi City. Their attendance was to provide food for the community in 1980 when the flood disaster came to happen. People who received foods, all of them were Muslim, signed a sheet of food recipients.

Furthermore, without the knowledge of the community, the recipients' signature sheet was misused by the Batak Christian Religious Leaders Group for fulfilling the requirements and a proof of local community support of building a Christian meeting hall in the area, both as a requirement and as. The meeting hall was eventually renovated into a church located only about 300 meters from the local community mosque building.

Since then, an eventual conflict happened. Local people rejected the presence of the Church that stands in the residential area of the Muslim community. However, the conflict did not lead to anarchism or other forms of violence against the minority of Church users. Wisely, religious and traditional leaders spoke up and advised the local community to report such an issue to the authorities. To this day, the Church building is still standing strong and well, none of the local people trying to do damage and or the like. Conflicts among religious adherents- the majority of which are indigenous Jambi and the minority of immigrant Christian religions - could be managed without rioting and rebellious conflicts. The case was ended up by the sealing of the Protestant Batak Christian Church (HKBP) Syalom Aurduri in Low Stingers, Jambi, in 1980.

Another conflict story was the building of the second church in Jambi City in the 1990s at Simpang Tanyo, Simpang Rimbo area, Natural Blasphemy Barajo. The incident began with the construction of a church by several Batak ethnic Christians on a 
plot of land in an area inhabited by a majority of Javanese, Sundanese, Bugis and Jambi Muslims, but most of the land in that location was owned by the Jambi Jambi people (across the city). The third conflict regarding the builiding of Christian places of worship in Jambi City took place in the West Ring Road area that was part of the Kotabaru region since 1990. It started with the purchase of land owned by Malays in the region. The many Batak people very costly bought it.

The continuing absence of religious conflicts related to the establishment of houses of worship in the city of Jambi has become a significant dispute that takes its toll on the victims and deserves appreciation from all components of the community. This is because sociologically, Jambi City is a plural region whose population consists of various religions (Islam, Christianity, Catholicism, Hinduism, Buddhism and Confucianism) and tribes (Malay, Batak, Palembang, Javanese, Buddhist, Madurese, Chinese, Arabic, India). The plurality of a region is, of course, a potential for conflict, as is the case in many countries and regions with pluralistic societies.

One answer to the lack of continuation of religious conflicts against the background of the establishment of houses of worship in the city of Jambi found the answers to aspects of the wisdom of local culture that grew and developed in the community. Wisdom of local culture is ideas that are born and developed in the local realm which contain wise, wise, and ethical values that are followed by all members of the community (Trubus Rahardiansyah and Prayitno 2011, 59). As stated earlier that although Jambi City consists of various ethnicities, Malay is the largest ethnic group in the composition of the population of this region. As part of the ethnic Malays, the people of Jambi City also have local cultural wisdom originating from customs or traditions that apply in society (Lembaga Adat Provinsi Jambi 2003, 18-21). 
The wisdom of the local culture of Jambi City is in the form of pantun or seloko arranged beautifully in the Jambi language like Gurindam in the Malay tradition. Generally, it is spoken out by the majority of the community. Seloko Adat is Jambi traditional literature that contains advice for safety and good life for the community (Lembaga Adat Provinsi Jambi 2003, 9). It is another type of Jambi traditional literature in addition to Petatah Petitih and Pantun Adat as the traditions of the community. The existence of Seloko Adat is an integral part of the literary system that exists in the archipelago known as human artistic creativity.

In practice, literature consists of essays, poems, saga, and drama that generally flourish in the cultural traditions of the Indonesian people. Despite being part of the archipelago literature, Jambi Malay literature does not yet exist, which is part of various types of Indonesian literature (Lembaga Adat Provinsi Jambi 2003, 5). As an old literary work, Seloko Adat is complicated to trace its source in the book, except through the indigenous speakers who are typically traditional figures. This was none other than the existence of Seloko Adat which was not written but was memorized by traditional Jambi Malay leaders who of course were already old.

Seloko Adat, which is used as a guide and Malay community guideline in the City of Jambi in carrying out its social life, are as follows:

First part:

Earth is safe for rice to become

Gravel on the island is diamond

Sand on the beach becomes gold

Green grass buffalo fat

the clear water of the fish is tame

Going to the fishing water gets fish

Pegi to land fruits become / durian collapses

Back to the food house out / chant childbirth 
Go to the mosque. The mosque is full

Enter the room pray; the room pray is tight

Where to meet friendly people smile.

The second part:

Where the earth is standing there, the heavens are upheld

Where the branches are broken there, water is lifted

Where the pan was broken there on the date of the pot-

tery

Where hoes are traced there plants grow

Where we live there can get a lot of money

We have to pay

Look far away, look close dipped

Keep banned by abstinence

In vain on earth, God perished

In vain in the village people are indebted

Seloko Jambi traditional Malay above is a guideline of the community in social life. This Seloko Adat guides people to understand the habits prevailing in the place where they live in harmony and preserve the relationship with nature. If practised, they will reach the safety of social life. Conversely, there is a price that must be paid in the form of customary sanctions if not heeded in accordance with what they have done.

\section{Internalizing mechanism of Jambi local culture as prevention of conflict}

As a plural area, Jambi City faces the threat of social conflict as conceptualized by many experts (Oetojo, 2010). This condition is of course what all the people of Jambi City do not want to cope with. There is no denial of the existence of religious circumstances in Jambi City. Historically, there were three incidents of religious conflicts related to the establishment of Christian places of worship in Jambi City, i.e., Telanaipura, Simpang Rimbo and Kota Baru. 
However, these three conflicts did not lead to significant conflicts, let alone claimed lives. This phenomenon arises question; why are the people of Jambi City not easily provoked to take anarchic actions? Even though Jambi City is a pluralistic region and very vulnerable to conflict, as in the case in many other areas similar to it. The study of Suaedy and Rumadi (2007, 247) proves that the history of religious conflict in Indonesia records places of worship has always been a source of conflict that frequently leads to destruction and burning.

Using the Coser's concept, Savety-Valve, what happens in Jambi as a pluralistic city will find the answer. Savety-Valve is a solution that can anticipate social conflict in a pluralistic society such as Jambi City. The Safety-Valve can be a representative body that provides a means to express complaints and problems faced by its members. This mechanism can also be in the form of a lecturer welfare committee which is the mouthpiece of the lecturers voicing the problems they face. In essence, the Safety valve functions as a regulator of the possibility of conflict and indirectly impedes the development of conflicting groups that can lead to change through conflict (Coser 1956, 109).

In the context of Jambi City, the non-introduction of community's anarchical actions is closely linked to the functioning of Savety-Valve, in the form of Jambi Malay Seloko Adat. One of the wisdoms of Jambi's local culture contains advice and guidance that can be used as a guide for the community in living social life. If the provisions are obeyed, the social life of the population will be safe and harmonious, but if it is the opposite, there will be conflict or conflict.

The function of Seloko Adat in inhibiting the occurrence of anarchical conflict certainly does not just happen. The effectiveness of one form of Safety-Valve is through a long process and is carried out in various ways. Therefore, public anarchism in- 
terpreted as destroying the social and physical order does not occur in Jambi City, which is well-known as a different region. The functioning of one of Jambi's local wisdom is closely related to its existence which has undergone a process of internalization in the community.

As a local wisdom that is very valuable for people's lives, Seloko Adat needs internalization so that anarchism does not arise in Jambi City. In this context, the internalization of Seloko Adat was carried out in 3 ways, namely: family, education and the environment. These are the three mechanisms which are the reasons behind the success of Seloko Adat to be Savety-Valve for the possibility of conflict in a pluralistic society inherent in Jambi City.

Internalization through the family is done by introducing and teaching Seloko Adat to children, both directly and by practising it. Parents familiarize their children with Jambi Malay culture, one of which is the Traditional Seloko. To the children, it was stated that as Jambi people, we have customary guidelines that govern our behaviour in the form of Indigenous Seloko. This method is carried out so that children as the next generation can get to know Seloko Adat earlier than their parents.

The other way to internalize of Seloko Adat is through education. As the party entrusted with the task of managing the region and the community, The Government of Jambi City deeply understands the existence and essential functions of Seloko Adat. Therefore, The Government of Jambi City has issued the Jambi City Regional Regulation Number 4 of 2014 concerning Lembaga Adat Melayu Tanah Pilih Pusako Betuah Kota (Malay Customary Institutions for Select Land and Sorcerer Heritage). One of the functions of this Institution based on the regional regulation is to enforce cultural values in the land of indigenous peoples of Jambi City can be carried out in daily life and keep it 
as local content in elementary schools, Junior high school, high school / vocational school and university.

The third way of trying to internalize of Seloko Adat into the community is through community meetings. As a region inhabited by a majority of Malay residents who are Muslim, community meetings are mostly held in religious contexts, such as commemorating Islamic holidays, weddings, donations, and weekly and biweekly visits.

These are the three mechanisms of internalization experienced by Seloko Adat so that it functions as a Savety-Valve as Coser said as a conflict prevention. Through these three ways of internalization of Seloko Adat can neutralize the possibility of a large conflict, especially related to the establishment of places of worship. Along with the dynamics of social life and the increasing flow of globalization that is increasingly fast, the mechanism of internalization must continue to be maintained. In fact, internal innovations must be carried out further so that the potential conflict inherent in Jambi City as a pluralist area can be avoided. In this way, the development agendas can be carried out properly without major social conflicts that can hinder them.

\section{Conclusion and Recommendation}

As a plural area, Jambi City is very vulnerable to social conflicts. There have been three social conflicts related to the church building. It has not end yet in terms of the social anarchism. Seloko Adat, in this case, functions as a rescue valve and internalizes within the community. Seloko Adat can contribute to the avoidance of Jambi City from anarchic religious conflict. Therefore, the government and the people of Jambi City can be benefitted from such local wisdom and should improve its internalization through a variety of well-organized positive activities. 


\section{Bibliography}

Agus, Bustanuddin. 2006. Agama Dalam Kehidupan Manusia: Pengantar Antropologi Agama. Depok: Rajagrafindo Persada.

Ayatrohaedi. 1986. Kepribadian Budaya Bangsa. Bandung: Dunia Pustaka Jaya.

Badan Pusat Statistik. 2016. "Kota Jambi Dalam Angka 2016." Jambi: BPS Kota Jambi.

Bakri, Hendry. 2015. "Resolusi Konflik Melalui Pendekatan Kearifan Lokal Pela Gandong Di Kota Ambon.” The POLITICS: Jurnal Magister Ilmu Politik Universitas Hasanud$\operatorname{din} 1$ (1): 51-60.

Boedhi Oetojo, Vina Salviana, Haryanto, Racmad K. Dwi Susilo, and Bambang Prasetyo. 2010. Sistem Sosial Budaya Indonesia. Tangerang Selatan: Universitas Terbuka.

Coser, Lewis A. 1956. The Functions of Social Conflict. New York: Routledge.

Crabtree, Benjamin F., and William L. Miller. 1999. Doing Qualitative Research. London: Sage Publications.

Creswell, John W., and Cheryl N. Poth. 2007. Qualitative Inquiry and Research Design: Choosing Among Five Approaches. London and New Delhi: Sage publications.

Denzin, Norman K., and Yvonna S. Lincoln. 2009. Handbook of Qualitative Research. Yogyakarta: Pustaka Pelajar.

Fisher, Simon, Jawed Ludin, Stave Williams, Dekha Ibrahim Abdi, Richard Smith, and Sue Williams. 2000. Mengelola Konflik: Keterampilan Dan Strategi Untuk Bertindak. Jakarta: British Council.

Idi, Abdullah. 2012. "HARMONI SOSIAL: Interaksi Sosial Natural-Asimilatif Antara Etnis Muslim Cina Dan Me- 
layu-Bangka." THAQAFIYYAT: Jurnal Bahasa, Peradaban Dan Informasi Islam 13 (2).

Jalaludin, Adon Nasrullah. 2015. Agama Dan Konflik Sosial: Studi Kerukunan Umat Beragama, Radikalisme Dan Konflik Antarumat Beragama. Bandung: Pustaka Setia.

Johnson, Doyle Paul. 1998. Teori Sosiologi Klasik Dan Modern. Translated by Robert MZ Lawang. Jakarta: Gramedia Pustaka Utama.

Kimball, Charles. 2008. When Religion Becomes Evil. San Francisco: HarperCollins.

Lembaga Adat Provinsi Jambi. 2003. "Dinamika Adat Jambi Dalam Era Global.” Jambi: Lembaga Adat Propinsi Jambi.

Lindayanti, Junaidi Tajuddin Noor, and Ujang Hariadi. 2013. Jambi Dalam Sejarah, 1500-1942. Jambi: Dinas Kebudayaan dan Pariwisata, Provinsi Jambi.

Lulofs, Roxane Salyer, and Dudley D. Cahn. 2000. Conflict: From Theory to Action. USA: Allyn \& Bacon.

Mariane, Irene. 2014. Kearifan Lokal Pengelolaan Hutan Adat. Depok: PT. RajaGrafindo Persada.

Miles, Matthew B., and A. Michael Huberman. 1992. Analisis Data Kualitatif. Translated by Tjetjep Rohendi Rohidi. Jakarta: UI press.

Mitchell, Bruce, Dwita Hadi Rahmi, and B. Setiawan. 2003. Pengelolaan Sumberdaya Dan Lingkungan. Yogyakarta: Gadjah Mada University Press.

Mufid, A. Syafi'i. 2010. "Revitalisasi Kearifan Lokal Dalam Pemberdayaan Masyarakat.” Harmoni 9 (34): 83-92.

Nasikun, J. 2004. Sistem Sosial Indonesia. Depok: Rajagrafindo Persada.

Poloma, Margaret M. 2004. Sosiologi Kontemporer. Depok: Raja Grafindo Persada. 
Robertson, Rolan. 1993. Agama Dalam Analisis Dan Interpretasi Sosiologi. Depok: Raja Grafindo Persada.

Rosdiawan, Ridwan, Zaenuddin Hudi, and Ibrahim M. Shaleh. 2007. "Merajut Perdamaian Di Kalimantan Barat." Revitalisasi Kearifan Lokal: Studi Resolusi Konflik Di Kalimantan Barat, Maluku, Dan Poso, 20-107.

Sartini. 2009. Mutiara Kearifan Lokal Nusantara. Yogyakarta: Kepel Press.

Sindung, Haryanto. 2012. Spektrum Teori Sosial: Dari Klasik Hingga Postmodern. Yogyakarta: Ar-Ruzz Media.

Suaedy, Ahmad, and Rumadi. 2007. Politisasi Agama Dan Konflik Komunal: Beberapa Isu Penting Di Indonesia. Wahid Institute.

Suprapto. 2013. "Revitalisasi Nilai-Nilai Kearifan Lokal Bagi Upaya Resolusi Konflik.” Walisongo: Jurnal Penelitian Sosial Keagamaan 21 (1): 19-38.

Trubus Rahardiansyah, P., and H. Arohman Prayitno. 2011. Transformasi Nilai Kearifan Lokal Dalam Pendidikan Bangsa: Dialektika Pentingnya Pendidikan Berbasis Local Genius. Jakarta: Penerbit Universitas Trisakti.

Wirawan, Ida Bagus. 2012. Teori-Teori Sosial Dalam Tiga Paradigma: Fakta Sosial, Definisi Sosial, Dan Perilaku Sosial. Jakarta: Kencana.

Yin, Robert K. 2004. Studi Kasus: Desain Dan Metode. Jakarta: Raja Grafindo Perkasa.

Zakaria, R. Yando. 1994. Hutan Dan Kesejabteraan Masyarakat Lokal. Jakarta: Wahana Lingkungan Hidup. 
This page intentionally left blank 